УДК 327.88:355.48(477:470)“2013-2016”

ПОЛЯНСЬКИЙ О. А.

https://orcid.org/0000-0002-0379-7591

https://doi.org/10.33577/2313-5603.33.2020.316-323

\title{
ДОСЛІДЖННЯ ПРО РОСІЙСЬКО-УКРАЇНСЬКУ ВІЙНУ ТАРАСА КУЗЯ
}

Кузьо Т. Війна Путіна проти Украӥни. Револючія, націоналізм і криміналітет. Київ, Дух і Літера, 2018. 560 с.

Книга британського та канадського політолога українського походження Тараса Кузя є грунтовним дослідженням причин i витоків російської агресії проти України, історії формування імперського ставлення російських еліт до України та українців, російськоукраїнських відносин після розпаду СРСР, а також нинішньої російської «гібридної війни» проти України. Автор навчався у Сассекському, Лондонському та Бірмінгемському університетах, працював у Єльському університеті, в Українській пресовій агенції, а сьогодні - старший науковий співробітник кафедри українознавства Торонтського університету. Рецензована книжка $є$ підсумком трирічного дослідницького проекту (2013 - 2016), який Т. Кузьо виконував не лише в наукових кабінетах, а й численних мандрівках Україною, зокрема в зоні бойових дій.

Як зазначає автор, дії теперішнього російського режиму в Україні, особливо анексія Криму, не просто відповідають амбіціям Путіна та його оточення, а $є$ надзвичайно популярними серед населення та політичних еліт, включно з низкою лідерів російської опозиції. Переконання Путіна в тому, що Україна мусить бути частиною «русского мира», а отже належати до євразійського, а не європейського інтеграційного проекту, підтримують мільйони росіян.

Варто наголосити, що упродовж століть українці протистоять московській експансії, яка розпочалася ще у XV ст. і до сьогодні визначає сутність російсько-українських взаємин. Новітня російськоукраїнська війна - це лише епізод 3 майже тисячолітнього протистояння двох націй - російської та української. Війни на знищення

Полянський Олег Арсенович, кандидат історичних наук, професор, завідувач кафедри гуманітарних дисциплін Львівського державного університету фізичної культури імені Івана Боберського

(C) Полянський О. А., 2020 
України вели московські царі, російські імператори, більшовицькокомуністичні генсеки й нинішні президенти Російської Федерації (Детальніше див.: В. Брехуненко, В. Ковальчук, М. Ковальчук, В. Корнієнко. «Братня» навала. Війни Росії проти України XIIXXI ст. Київ, 2016. 248с.; М. Дорошко. Неоголошені війни Росії проти України у XX - на початку XXI ст.: Причини і наслідки. Київ, 2018. 196 с.)

Хоча в центрі уваги дослідника нинішня російсько-українська війна, іiі передумови, причини та особливості, все ж, Т. Кузьо часто робить історико-політологічні екскурси в багатовікове протистояння України і Росії і на відміну від багатьох інших західних інтелектуалів називає речі своїми іменами. Для прикладу візьмемо назви окремих розділів його праці: «Нова «холодна війна»: Росія веде війну із Заходом та Україною», «Російський націоналізм й імперіалізм та Україна», «Українофобія та ресталінізація», «Національна ідентичність України та війна Путіна» та ін.

Зважаючи на те, що у Торонто спершу вийшов англомовний варіант книжки (2017р.), а згодом появилися українсько- та російськомовні видання (2018 р.), особливого смислового навантаження набувають принципові зауваження автора про те, що упродовж минулого десятиліття Росія використовувала Естонію, Грузію, а особливо Україну як тестові майданчики для розвитку свого гібридного, інформаційного та кібернетичного потенціалу, вістря якого вона спрямувала проти цілої низки західних країн по обидва боки Атлантики. Сподівання на те, що Путін обмежить своє втручання діями проти країн, котрі не належать до НАТО, як от Грузія чи Україна, було ілюзорним. Росія вдалась до гібридної та інформаційної війни й війни в кіберпросторі проти багатьох членів Альянсу: Естонії, Великої Британії, Німеччини, Норвегії, Нідерландів, Франції, Греції, Угорщини, Болгарії, Туреччини, Чорногорії та ін.

На ці кричущі факти порушення Росією загальноприйнятих міжнародних норм не реагують належним чином лідери Свропи потенційні кандидати на високі й добре оплачувані посади в російському «Газпромі» з Німеччини, Франції, Італії, Чехії, Угорщини, Сербії та деяких інших країн. Тим часом шовіністичні щупальці московського імперіалізму, як ракові метастази, проникли й обплутали увесь світ й загрожують національній безпеці навіть США. Хвиля політиків-популістів накрила й держави класичної демократії.

Відштовхуючись від тези про небажання Росії визнати українців окремим народом, що українська мова - це повноцінна мова, а не 
діалект російської, що українці мають незалежну державу та право визначати власну геополітичну долю, що начебто російська мова, а не громадянство РФ, є основним маркером ідентичності в російськомовній спільноті, Т. Кузьо аналізує різні форми російського націоналізму, які часом переростали у фашистські й неонацистські ідеології. Він, зокрема, детально розглядає т.зв. «євразійство», яке здобуло ключову роль у путінській Росії. Особливо прискіпливо політолог зупиняється на характеристиці одіозного російського нациста Дугіна, його расистських теоріях, впливі на російський істеблішмент, зокрема Путіна. Т. Кузьо погоджується 3 думкою ще одного дослідника українського походження О. Мотиля, який вважає, що після шістнадцяти років перебування Путіна при владі російська політична система еволюціонувала до фашистської, а сам кремлівський «цар», після переобрання на троні 2012 року, цілковито пристав на націоналізм, «консервативні цінності», імперіалізм і ксенофобію.

Така позиція й агресивні дії Путіна стали можливими завдяки підтримці цієї політики російським суспільством, в т.ч. росеміграції. Так, Т.Кузьо звертає увагу на відкритий лист ста нащадків російських аристократів-емігрантів на підтримку Путіна в контексті війни на Донбасі.

Тому можна повністю погодитись 3 висновками дослідника щодо консенсусу російського націоналістичного мислення про Україну як штучної конструкції, що східну та південну Україну й Крим слід «повернути» Росії. Російські емігранти всіх ідеологічних мастей, російські патріоти в Радянському Союзі, колишній дисидент Солженіцин і президент Путін погоджувалися 3 потребою розчленування України, аби Схід і Південь стали частиною Росії, а решта теренів залишились псевдосамостійним домініоном під російським контролем, натомість Західна Україна може йти власним шляхом, але краще, щоб їі анексувала Польща.

Аналізуючи українофобію та ресталінізацію в сучасній Росії, Т. Кузьо підкреслює, що російські компанії проти «українського сепаратизму та націоналізму» беруть свій початок з часів Полтавської битви 1709 р. та спроби гетьмана Івана Мазепи визволитися iз «братніх російських обіймів». «Упродовж наступних трьох століть, - пише він, - тема «зради» та причетності західних урядів до українських політичних проектів, покликаних ослабити Росію, становили осердя українсько-російських відносин [...] Українці 
в царському, радянському та російському світогляді були не самостійними дійовими особами, а лише пішаками у змовах австрійців під час Першої світової війни, нацистської Німеччини у Другій світовій війні , західних та ізраїльських спецслужб у часи «холодної війни», а зрештою США та ЄСу «просуванні демократії». [...] У Російській імперії українці мусили обирати між тим, щоб «погодитися на переслідування як «мазепинці», на самознищення як «малороси» чи на зневагу як «хохли».

Для глибокого розуміння сутності подій, що відбулися у 2014 р. в Криму та Донбасі, надзвичайно важливим є розділ книги Т. Кузя «Злочинність і насильство». Ще японський дослідник Гіроакі Куромія зазначав, що організовані злочинні угруповання (ОЗУ) здавна існували на Донбасі. Сюди після Другої світової війни мігрували чи були скеровані з інших регіонів СРСР для роботи на шахтах $\mathrm{i}$ заводах 3,5 млн робітників і звільнених в'язнів. Серед них були особи з сумнівним минулим, ті, хто хотів змінити свою тотожність і приховати сімейний стан, соціальні ізгої, а також біженці, злочинці, остарбайтери, колишні військовополонені та ін. Наявність значного числа злочинців, авантюристів і безпритульних була своєрідною візитною карткою Донбасу і сприяла високому рівню тут злочинності.

У книжці Т. Кузя наводяться вражаючі факти зв'язків В. Януковича, Р. Ахметова, В. Колесникова, як і загалом Партії регіонів, iз кримінальним світом: «За правління Януковича Україна, що до цього була корумпованою державою, перейшла від олігархічної економіки до мафіозної. [...] Янукович і його найближче оточення... викрали з держбюджету від 40 до 100 млрд доларів».

Принциповий висновок дослідника полягає в тому, що вся державна влада на Донбасі підпорядковувалася кримінально-олігархічному клану, політичним прикриттям якого слугувала Партія регіонів. Історія створення цієї корумповано-мафіозної структури, вражаючі факти з біографій іï діячів, насамперед Р. Ахметова, В. Януковича, а також А. Брагіна, В. Колеснікова, братів Клюєвих цих «хазяїнів» Донбасу, розкривають читачам справжню злочинну сутність регіонального клану, який свої донецькі «заморочки», свою бандитську субкультуру переніс на всю Україну. Звідси однозначний висновок Т. Кузя: «Вбивства Брагіна та Євгена Щербаня, а також ліквідація банди Кушніра проклали шлях нагору для тріо Ахметов-Янукович-Колесніков й «легалізації» членів організованих 
злочинних угруповань в ролі політиків». Тому силові методи Януковича та його кліки проти євромайдану, насильство і вбивства «не мають дивувати тих, кому відоме минуле депутатів парламенту від Партії регіонів. [...] Вони розглядали насильство як незмінний інструмент у політиці, грунтуючись на своєму попередньому досвіді.... Аби протистояти Майдану, бойовиків, зібраних звідусіль на сході та півдні України, включно з Кримом, залучили до взаємодії 3 міліцейським спецпідрозділом «Беркут», і внутрішніми військами МВC. [...] Основний корпус бойовиків, який складали вихідці із Донецька та Харкова, фінансували син президента Олександр Янукович, Юрій Іванющенко та Олександр Єфремов. Ресурси міської міліції були надані Захарченком, який дбав про координацію, підбір і фінансування «тітушок» з відома глави держави. [...] У Харкові агресивні бойовики з угруповання «Оплот» співпрацювали 3 міським головою Геннадієм Кернесом, який сам був вихідцем iз криміналітету. [...] Членів «Оплоту» тренували, фінансували та екіпірували російські розвідники, частину яких таємно перекинули на схід України ще за кілька років до описуваних подій. [...] Навесні 2014 року на значній частині території Донбасу українська влада перестала функціонувати, виник політичний і правовий вакуум, який заповнили російські окупанти, маргінальні досі проросійські націоналістичні й панславістські партії, парамілітарні організації та злочинні угруповання».

Ми навели таку досить обширну цитату із книги Т. Кузя для глибшої та яскравішої характеристики ситуації в Україні наприкінці 2013 - на початку 2014-го років. А коли до цього додати ще й кримські реалії, постає похмура картина прірви на краю якої опинилася Україна у цей період. Як зазначає Т.Кузьо, у парламенті Автономної Республіки Крим та органах самоврядування на місцях Партія регіонів об'єднала велику кількість колишніх та діючих кримінальних авторитетів. У ході анексії півострова Росія значною мірою спиралася на місцеву організовану злочинність «строкату банду місцевих активістів і кримінальників, суміш ультраправих радикалів і нікчем», одним із лідерів яких був Сергій Аксьонов, що у 90-их роках очолював «бригаду» ОЗУ «Сейлем» і мав кримінальне прізвисько «Гоблін», а нині це «глава» окупаційної адміністрації Криму підконтрольної Кремлю. Певне місце у книзі Т. Кузя відведено й уродженцеві Тернопільщини Дмитрові Фірташу - «багаторічному російському агентові впливу в Україні». 
Привертає до себе увагу принциповий висновок дослідника: «Фронтирний характер життя на Донбасі був пов'язаний з міграціями, насильством та тюремною субкультурою. Регіон приваблював людей без роду і племені: тут можна було сховатись і почати нове життя, а засудженим злочинцям зменшували вироки за роботу на копальнях. [...] У 1995-1999 роках, після усунення чільних кримінальних й олігархічних противників, Янукович $\mathrm{i}$ Ахметов встановили контроль над Донбасом завдяки вкрай корумпованим стосункам, де перший забезпечив другому політичний «дах», даючи їм обом змогу швидко розбагатіти».

У контексті теми «Війна Путіна проти України» особливий концептуальний характер мають розділи: «Донбас і Україна», «Підрив і розчленування України», «Вторгнення, анексія та гібридна війна», «Національна ідентичність України та війна Путіна». У них на конкретних фактах доказово розкрито і яскраво висвітлено специфіку й особливості політичної, економічної та духовнокультурної ситуації на Донбасі наприкінці XX - на початку XXI ст. Вихідна теза Т. Кузя: «Донбас, як і Крим, завжди мав амбівалентні стосунки з рештою України».

Для сутнісного розуміння, що таке Донбас, який влада намагається інтегрувати/вмонтувати в Україну, наведемо деякі цифри і факти. Починаючи з 1870-х років, Донбас масово заселяли росіянами зі Смоленської, Тульської та Курської губерній. У 1884 р. 71\% мешканців Юзівки (Донецька) становили росіяни. У 1917 р. в Юзівці мешкало 32 тис. росіян, 10 тис. євреїв і лише 7 тис. українців, а в 1923 р. українці складали всього 7\% мешканців міста, у 1989 р. 43\% жителів краю налічували етнічні росіяни. Тому має абсолютну рацію політолог, який підкреслює, що наприкінці 1980-х років етнічні українці Донбасу відчували себе подібно до корінних народів Америки чи Австралії. Як в таких умовах змогли появитися тут такі видатні українці, як Василь Стус, Іван Дзюба, Надія та Іван Світличні, Микола Руденко та Петро Григоренко, можна лише дивуватися.

Т. Кузьо зауважує, що ідеї сепаратизму були популярними серед донецького клану всі роки незалежності, ними він постійно погрожував Києву. Попри проросійську риторику, донбаські олігархи та регіональні еліти значну частину свого життя проводили в Свропі, де у тамтешніх банках тримали й тримають свої вкрадені гроші, там, в Свропі, вони мають нерухомість, відпочивають, вчать 
дітей, а Україну вважають чимось на зразок колонії, звідки отримують високу ренту, за яку не сплачують податків, а кошти переводять в офшорні податкові схованки. Найяскравіший приклад кримінальний авторитет донецької мафії Рінат Ахметов, за прямого сприяння якого на Донбасі було розв'язано російсько-українську війну. А нині він цинічно надає гуманітарну допомогу мешканцям краю чи блюзнірськи тішить обивателів своїм дітищем - «Шахтарем». Тому дуже неоднозначним є повернення тих 13\% окупованої донбаської території до складу України.

У книзі проводиться думка, що в основі російсько-української війни була не просто імперіалістична політика Москви та іiї президента Путіна, а також такі чинники, як неспроможність більшості мешканців Російської Федерації визнати, що українці є окремим народом, широко розповсюджена теза про те, що Україна не $є$ незалежною і суверенною державою, а лише інструментом, за допомогою якого Захід сприяє ослабленню Росії, а також російська точка зору, згідно з якою Крим і населені російськомовними громадянами Схід і Південь України були помилково включені за СРСР до складу України.

Зрештою, прийшовши до влади Путін не приховував своїх реваншистських, ксенофобських та українофобських поглядів, які були чітко сформульовані ним в промові на Мюнхенській конференції з питань безпеки (2007 р.) та Бухарестській раді НАТО Росія (2008 р.). Вторгнення у Грузію 2008р., яке, при потуранні Заходу, зійшло Путіну з рук, заохотило кремлівського вождя до анексії Криму та збройної інтервенції на Донбасі.

Прийшовши до влади Янукович і його кліка розпочали демонтаж Української Держави. Насамперед він підписав зрадницькі Харківські угоди з Москвою, за якими перебування Чорноморського флоту Росії у Севастополі продовжено до 2042-2047 pp. Українські силові структури (зрештою не лише силові) були наводнені агентами Росії: «У роки президентства Януковича російське ГРУ створило глибоко законспіровану, але добре структуровану мережу агентів, пов'язану із проросійськими організаціями, що займаються незаконною діяльністю в багатьох частинах України». Громадяни Росії Д. Саламатін, П. Лєбєдєв були міністрами оборони України, як і очільники СБУ О. Якименко й І. Калінін.

Т. Кузьо наводить у своїй праці вражаючі факти і цифри зазначає, що ФСБ тримала СБУ під контролем і мала повні дані 
про 22000 співробітників та інформаторів. Напередодні вторгнення в Україну жорсткі диски і флеш-накопичувачі з оперативною інформацією або доправили в Росію, або знищили. До рук ФСБ потрапило все, що є основою для фахової розвідки. ФСБ також контролювала мобільну телефонну мережу України. Навесні 2016 р. СБУ опублікувала список 1391 свого співробітника, які перейшли на бік Росії в Криму, чимало з них продовжили службу як офіцери ФСБ. Заступник командувача АТО, високий за званням офіцер СБУ виявився російським агентом. Після Свромайдану в лавах СБУ було заарештовано 235 іноземних агентів. Перехід більшості офіцерів та персоналу МВС, СБУ, армії та прокуратури Криму на бік ворога, пише Т. Кузьо, є одним з найбільших актів державної зради в сучасній європейській історії. У Бахчисарайському р-ні $80 \%$ військових, 90\% прокурорів і 100\% співробітників СБУ та MBC за одну ніч змінили свою присягу з української на російську.

У книзі послідовно і логічно показано обставини російського вторгнення та анексії Криму, специфіку гібридної війни на Донбасі. За попередніми підрахунками, величезний арсенал російської військової техніки, що була надана донбаським сепаратистам, включала 600 танків, 1300 БТР, 700 артилерійських гармат і 500 реактивних систем залпового вогню. Всі офіцери середньої та найвищої ланки збройних формувань, які протистоять Україні, є росіянами. Загальне керівництво збройними формуваннями російських маріонеток здійснював заступник командувача Сухопутних військ Росії генералполковник Алєксандр Лєнцов. Російських генерал-лейтенантів Валєрія Асанова та Сєргєя Юдіна, генерал-майорів Алєксєя Завізьона, Сєргєя Кузовлєва та Євгенія Нікіфорова було ідентифіковано як осіб, які почергово командували армійськими корпусами російських маріонеток.

Тому потрібно погодитись 3 висновками автора: «Підгрунтям війни Путіна проти України, найбільшої кризи в Свропі від часів Другої світової війни, стали неспроможність змиритися із втратою імперії, невміння розставити пріоритети й зосередитися на створенні російської національної держави, замість того, щоб вибудовувати різні наддержавні утворення. [...] Після агресії, вчиненої у 2014 та наступних роках, відносини Росії з Україною та навколишнім світом у цілому більше ніколи не будуть такими, як раніше». 